University of Nebraska - Lincoln

DigitalCommons@University of Nebraska - Lincoln

Publications, Agencies and Staff of the U.S.

Department of Commerce

U.S. Department of Commerce

$10-2008$

\title{
Demographics and Spatio-Temporal Signature of the Biotoxin Domoic Acid in California Sea Lion (Zalophus californianus) Stranding Records
}

\author{
Adriana Bejarano \\ NOAA/NOS, Hollings Marine Laboratory \\ Frances Gulland \\ The Marine Mammal Center \\ Tracey Goldstein \\ The Marine Mammal Center \\ Judy St. Leger \\ SeaWorld San Diego \\ Michele Hunter \\ Pacific Marine Mammal Center \\ See next page for additional authors \\ Follow this and additional works at: https://digitalcommons.unl.edu/usdeptcommercepub \\ Part of the Environmental Sciences Commons
}

Bejarano, Adriana; Gulland, Frances; Goldstein, Tracey; St. Leger, Judy; Hunter, Michele; Schwacke, Lori; VanDolah, Frances; and Rowles, Teri, "Demographics and Spatio-Temporal Signature of the Biotoxin Domoic Acid in California Sea Lion (Zalophus californianus) Stranding Records" (2008). Publications, Agencies and Staff of the U.S. Department of Commerce. 13.

https://digitalcommons.unl.edu/usdeptcommercepub/13

This Article is brought to you for free and open access by the U.S. Department of Commerce at DigitalCommons@University of Nebraska - Lincoln. It has been accepted for inclusion in Publications, Agencies and Staff of the U.S. Department of Commerce by an authorized administrator of DigitalCommons@University of Nebraska - Lincoln. 


\section{Authors}

Adriana Bejarano, Frances Gulland, Tracey Goldstein, Judy St. Leger, Michele Hunter, Lori Schwacke, Frances VanDolah, and Teri Rowles 


\title{
Demographics and spatio-temporal signature of the biotoxin domoic acid in California sea lion (Zalophus californianus) stranding records
}

Adriana C. Bejarano

NOAA/NOS, Hollings Marine Laboratory, 331 Fort Johnson Road, Charleston, South Carolina 29412, U.S.A.

E-mail: bejaranoac@gmail.com

Frances M. GulLAND

TRACEY GOLDSTEIN

The Marine Mammal Center, 1065 Fort Cronkhite, Sausalito, California 94965, U.S.A.

\author{
JUDY ST LEGER \\ SeaWorld San Diego,
}

500 SeaWorld Drive, San Diego, California 92109, U.S.A.

MiCHELE HunTER

Pacific Marine Mammal Center,

20612 Laguna Canyon Road, Laguna Beach, California 92651, U.S.A.

LORI H. SCHWACKE

NOAA/NOS, Hollings Marine Laboratory,

331 Fort Johnson Road, Charleston, South Carolina 29412, U.S.A.

Frances M. VANDOlah

NOAA/NOS, Center for Coastal Environmental Health and Biomolecular Research, 219 Fort Johnson Road, Charleston, South Carolina 29412, U.S.A.

\section{TERI K. ROWLES}

NOAA Fisheries, Office of Protected Resources, 1315 East West Highway, Silver Spring, Maryland 20910, U.S.A.

\begin{abstract}
California sea lions (Zalophus californianus) in otherwise good nutritional condition have been consistently affected by the marine biotoxin domoic acid since the late 1990s. In this study we evaluated the temporal and spatial stranding patterns of suspected and confirmed cases of domoic acid intoxicated sea lions from 1998 to 2006, using records of strandings along the California coast obtained from members of the California Marine Mammal Stranding Network. The majority of domoic acid cases were adult females ( $47 \%-82 \%$ of the total annual domoic acid cases), a contrast to strandings that were not related to domoic acid, which were generally
\end{abstract}


dominated by juveniles and pups. Exposure to this biotoxin led to a 6.67 -fold increase in adult female strandings in 2000, and a 5.44-fold increase in adult female deaths in 2006, relative to strandings and deaths of adult female not affected by domoic acid. Domoic acid cases have occurred annually since 1998 (except for 1999) between April and August, with clusters centered primarily at Pismo Beach (San Luis Obispo County), as well as at other beaches in San Luis Obispo, Monterey, Santa Cruz, Santa Barbara, Orange, and San Diego counties. The larger ecological and population level implications of increased domoic acid strandings and deaths, particularly among adult female sea lions, warrant further attention and need to be investigated.

Key words: California sea lion, Zalophus californianus, stranding patterns, biotoxin domoic acid.

Unusual mortality and stranding events involving hundreds of marine mammals within a relatively short period of time have been documented along the California coast for at least four decades (Gulland 2000). The California sea lion (Zalophus californianus) is one of the species most commonly associated with these stranding events. Sea lion strandings involving dozens to hundreds of animals have been attributed to prey fluctuations related to changes in oceanographic conditions such as El Niño, bacterial diseases such as leptospirosis, and more recently to the marine biotoxin domoic acid (Gulland and Hall 2007).

During El Niño, warmer sea surface temperatures and deeper thermoclines along the eastern Pacific lead to reduced upwelling of nutrient-rich cold water, and reduced primary and secondary productivity, thus affecting food supply to top predators (Trillmich and Ono 1991). Fluctuations in the food supply during El Niño force female sea lions to increase the time they spend foraging at sea and away from nursing pups, resulting in poor nutritional condition that leads to reduced fecundity, and increased female and pup mortality (DeLong et al. 1991, Francis and Heath 1991, Melin 2002). These effects are reflected in low pup abundance during El Niño years (Lowry and Forney 2005). California sea lion strandings associated with El Niño have been well documented for the 1982-1983 (Trillmich and Ono 1991), 1992-1993 (Greig et al. 2005), and 1997-1998 El Niño years (Greig et al. 2005).

Leptospirosis is an infectious bacterial disease (Leptospira spp.) responsible for frequent cyclic epizootics among California sea lions dating back to the 1970s (Gulland et al. 1996). This disease targets primarily the kidneys and, although it affects all age classes, is most common in juvenile and subadult males during their northern migration from the rookeries to Washington and British Columbia (Gulland et al. 1996, Greig et al. 2005). Leptospirosis has also been linked to increased abortion rates and reproductive failure in females and to multiple hemorrhagic syndromes in fetuses and neonates (Smith et al. 1974). California sea lion stranding events associated with this disease have been reported for 1984 (Dierauf et al. 1985), 1991 (Gulland et al. 1996), 1994-1995 and 1999-2000 (Greig et al. 2005), and 2004 (Raverty et al. 2005).

The effects of domoic acid on California sea lions have been less extensively studied compared to those of El Niño and leptospirosis. California sea lion stranding events associated with this biotoxin are relatively more recent and have been well documented for 1998 (Gulland 2000, Scholin et al. 2000), 2000 (Gulland et al. 2002, Mazet et al. 2005) and 2005 (Goldstein et al. 2008). Domoic acid, produced 
by several marine diatom species of the genus Pseudo-nitzschia, is highly toxic because of its structural resemblance to the naturally occurring excitatory neurotransmitter glutamate. Binding of domoic acid to neurotransmitter receptors in the brain causes partial opening of ion channels, resulting in prolonged receptor activation and constant influx of cations into the neurons, leading to neuronal degeneration and death (Hampson and Manalo 1998). Clinical signs in marine mammals associated with domoic acid neurotoxicity include ataxia, scratching, seizures and coma (Gulland 2000), as well as neurological disorders lasting several weeks to months post-exposure (Goldstein et al. 2008). These signs are linked to domoic acid-induced neuronal loss and hippocampal degeneration (Gulland 2000). Increased frequency of toxic Pseudo-nitzschia blooms since the mid-1990s has coincided with the beginning of a multidecadal $(\sim 25 \mathrm{yr})$ regime shift, characterized by cooler ocean temperatures, stronger upwelling, increased nutrient supply, and increased phytoplankton productivity and anchovy abundance (Chavez et al. 2003). Algal blooms along the California coast initiate during the spring, with toxic blooms often developing during late summer and fall, when influx of nutrient-rich water from adjacent upwelling regions subsides (Horner et al. 1997, Trainer et al. 2000).

The California sea lion population, which includes the U.S. and the western Baja California (Mexico) subpopulations, was estimated at 237,000-244,000 individuals in 2003 (NMFS 2003). This population concentrates during the breeding season (May-August) south of $34^{\circ} \mathrm{N}$, particularly on the Channel Islands (largely on San Miguel and San Nicolas islands) and on islands in western Baja California. Throughout the non-breeding season (August-May) females remain close to the islands, alternating periods between nursing on the rookeries and foraging trips, while subadult and adult males migrate north along the coast, returning south only to breed (Bartholomew 1967, Peterson and Bartholomew 1967, DeLong et al. 1973, Mate 1975, Le Bouef et al. 1976, Odell 1981). From 1975 to 2000, the U.S. California sea lion stock grew at an exponential rate ranging from $5.8 \%$ to $6.1 \%$ per year (Lowry and Maravilla-Chavez 2005). Because domoic acid has caused reproductive effects, including abortion and premature parturition of pups, and elevated death of pregnant female sea lions since 1998 (Brodie et al. 2006), it is essential to continue evaluating its effects on the sea lion population through the information generated from stranding records.

For this study we compiled California sea lion stranding data from 1998 to 2006 made available by members of the California Marine Mammal Stranding Network and classified each stranding as a confirmed domoic acid case, a suspected domoic acid case, or a case unrelated to domoic acid (i.e., other cause). We then compared the demographic, temporal and spatial patterns of domoic acid cases (suspected plus confirmed) with non-domoic acid cases to better understand the likely impacts of this biotoxin on the U.S. California sea lion population.

\section{METHODS}

\section{Compilation of Stranding Data}

Investigations of marine mammal strandings along the California coast are conducted by members of the California Marine Mammal Stranding Network. Network participants respond to strandings of live and dead marine mammals and collect information including location, morphological data, findings related to human 
interaction, and live animal disposition or carcass status. Some participants also provide veterinary care for live-stranded animals, conduct necropsies of dead animals, and collect samples for toxin analysis. From this supplemental information, the cause of the stranding can often be determined.

Current California sea lion stranding records and information on the cause of death were requested from multiple participants of the California Marine Mammal Stranding Network. Records were obtained from 1998 to 2006 from three rehabilitation centers: The Marine Mammal Center (TMMC, Sausalito, CA), Pacific Marine Mammal Center (PMMC, Laguna Beach, CA), and SeaWorld San Diego (SWSD, San Diego, CA). These data sources provided the National Marine Fisheries Service database (NMFS, NOAA Fisheries Service) with 30\%-45\% of the total annual California sea lion stranding records from 1998 to 2005. Information from TMMC encompassed 1998 to 2006 and included locations from Los Angeles County to Mendocino County (Fig. 1). Cases from TMMC for October, November, and December of 2006 were not included because these data were not yet available. PMMC provided data from 2002 to 2006 and included stranding locations from Orange

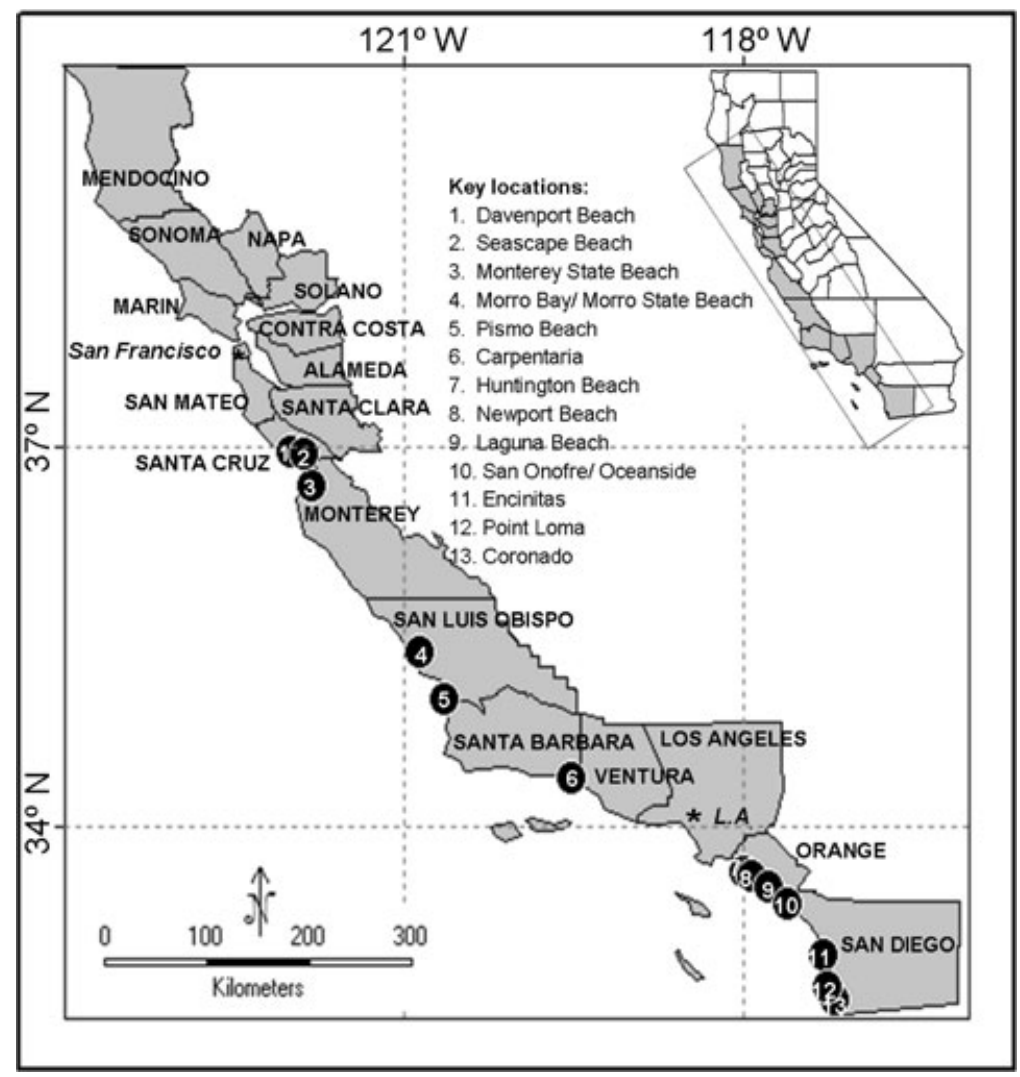

Figure 1. Map of California showing coastal counties (in gray) from which California sea lion stranding records (domoic acid and non-domoic acid cases) were included. Locations (numbered from north to south) represent key areas mentioned herein. 
County to San Diego County. Records from PMMC prior to 2002 did not include the cause of death or stranding, thus were not included here. Data from SWSD covered 1998-2006 and locations exclusively in San Diego County. Stranding records from the two northern most counties (Del Norte and Humboldt) were not included because none of the stranding network facilities that provided information cover these areas.

\section{Classification of Domoic Acid Cases}

In this study domoic acid strandings included all confirmed and suspected biotoxin cases. Confirmed domoic acid cases included those animals with hippocampal lesions and/or detection of the biotoxin in body fluids (urine, blood) or feces (Gulland 2000). Suspected domoic acid cases included dead animals without signs of trauma or chronic infection that stranded in the vicinity of domoic acid cases, as well as sea lions in good nutritional condition exhibiting seizures, severe disorientation, and scratching behavior characteristic of domoic acid intoxication and without signs of trauma or chronic infection (Gulland 2000). Information from all cases included stranding location and date, sex, age class, disposition (live or dead), and restranding notes. Age classes were defined as pup ( $0-2 \mathrm{yr})$, juvenile female $(2-5 \mathrm{yr})$, and male ( $2-4 \mathrm{yr}$ ), subadult male ( $4-8 \mathrm{yr})$, adult female ( $>5 \mathrm{yr})$, and male ( $>8 \mathrm{yr})$.

\section{Demographics of Stranding Patterns}

Sex/age-class frequency distribution of strandings were computed for cases not related to domoic acid and compared with the observed sex/age-class distribution of domoic acid strandings using a $G$-test (Sokal and Rohlf 1995; STATISTICA, Tulsa, OK). In two of the study years (1998 and 2003) there were significant El Niño events, which likely increased pup mortality and could potentially alter the typical age-class distribution of strandings. Therefore, we repeated the analysis excluding these two El Niño years. In order to assess the effect of this biotoxin on adult females, annual increased stranding and death among exposed adult females was calculated relative to adult females that stranded or died from causes other than domoic acid (domoic acid stranding or death/stranding or death from other causes).

\section{Temporal and Spatial Signature}

Analysis of the temporal stranding signature for both non-domoic acid and domoic acid cases, regardless of the stranding location, was carried out via contour plots of monthly strandings by year (Systat, Chicago, IL). Contour plots were generated using running average smoothing, a procedure that removes data noise using the nearest neighbors technique (Cleveland 1993). This technique was also used to define annual peaks of domoic acid strandings as well as to define the approximate duration of these events.

Spatial analysis was performed on all domoic acid cases for which stranding locations were available. Since the exact longitude and latitude was not always provided, coordinates were manually assigned based on the reported stranding location. To ensure that only acute domoic acid cases were included in the analysis, all records of restranded animals $(n=7)$ were removed from the analysis, with the exception of animals that re-stranded 5 mo or more after their first stranding. This arbitrary cutoff was necessary to ensure unique records, and to exclude the effects of chronic 
domoic acid cases on stranding signatures (Goldstein et al. 2008). In order to identify geographically distinct groups of domoic acid cases, $k$-means clustering analysis was performed based on the longitudinal attributes of each stranded animal (Systat). This non-hierarchical method minimizes within-cluster variance and maximizes variability between clusters, producing tight, non-overlapping clusters. The number of clustering groups was specified a priori following visual examination of data, and based on coherent and geographically proximal clusters (Kaufman and Rousseeuw 1990).

\section{RESULTS}

\section{Demographics of Stranding Patterns}

This study compiled 3,944 records of sea lions that stranded or died from causes unrelated to domoic acid, and 1,335 records of animals that stranded or died from exposure to the biotoxin. In both these groups of animals, nearly half died or were euthanized. The sex/age-class distribution of domoic acid strandings vs. strandings from other causes differed significantly $(G=3,472$, df $=6, P<0.0001)$. The majority of cases not related to domoic acid comprised pups (59\%, 2,327 cases) even during non-El Niño years, followed by juvenile males (18\%, 710 cases; Fig. 2). In contrast, domoic acid cases were predominantly adult females $(68 \%, 910$ cases) and followed by juveniles (16\%, 215 cases). The difference in sex/age-class distribution between domoic acid and non-domoic acid cases remained highly significant even when data from the El Niño years (1998 and 2003) were excluded $(G=2,800, \mathrm{df}=$ $6, P<0.0001)$.

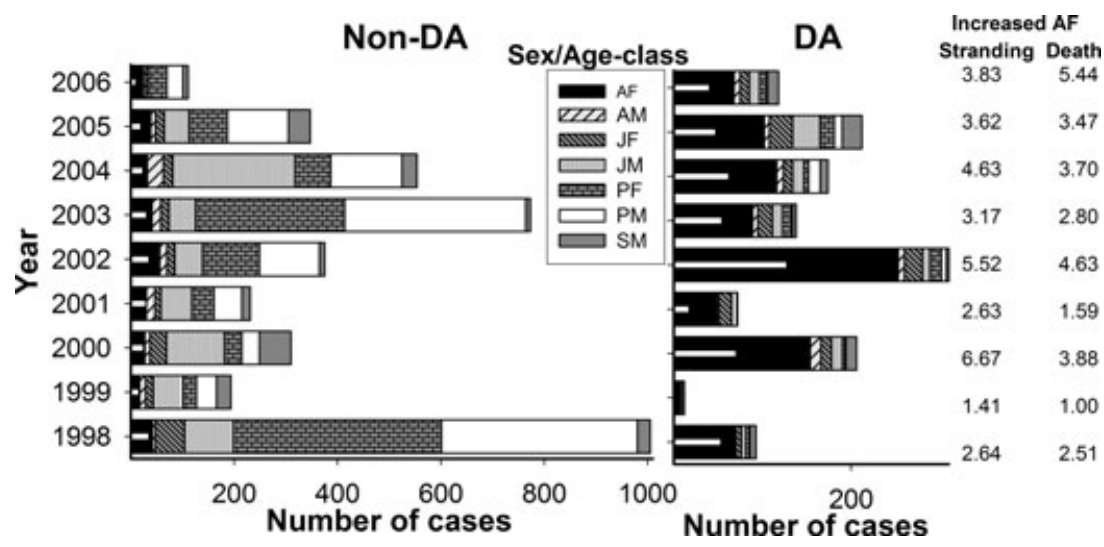

Figure 2. Non-domoic acid and domoic acid California sea lion cases from 1998 to 2006 across all sex/age classes. Gray scale bars represent the total number of stranding cases (live and dead), while thin white bars represents number of adult female deaths (dead stranded plus euthanized) per year. The numbers on the right indicate the annual increase in adult female stranding and death associated with domoic acid intoxication, relative to annual adult female stranding and death not related to the biotoxin (domoic acid death or stranding/death or stranding not related to the biotoxin). $\mathrm{AF}=$ adult female, $\mathrm{AM}=$ adult male, $\mathrm{JF}=$ juvenile female, $\mathrm{JM}=$ juvenile male, $\mathrm{PF}=$ pup female, $\mathrm{PM}=$ pup male, and $\mathrm{SM}=$ subadult male . El Niño years: 1998, 2003. 
We further evaluated the effects of domoic acid on adult females by comparing the annual number of cases not related to domoic acid with the number of cases related to the biotoxin. Over the nine-year study period, the number of adult females that stranded with domoic acid intoxication (910 cases) were three times the number of adult females that stranded from other causes (308 cases), and the number of adult females that died (on-site or euthanized) from domoic acid intoxication (469 cases) was twice the number of adult female deaths not related to the biotoxin (219 cases). However, both the number of adult female strandings and deaths caused by domoic acid was highly variable. On an annual basis and relative to adult females not affected by the biotoxin, adult female strandings increased from 1.41 in 1999 to 6.67 in 2000, and adult female death ranged 1.00 in 1999 to 5.44 in 2006 (Fig. 2).

\section{Temporal and Spatial Signature}

The contour plot of stranding cases not related to domoic acid (Fig. 3; $n=3,944$ ) illustrates an increase in the number of strandings in the summer of 2002 and 2003, particularly among pups (14.3\% May and $12.5 \%$ June). By contrast, the contour plot of the domoic acid stranding cases $(n=1,335)$ illustrates relatively large events during May 1998, June-July 2000, April-May 2002, and July-August 2005. These events resulted in an elevated cumulative stranding frequency, particularly of adult females (24.6\% of all domoic acid cases), in May. Stranding peaks associated with domoic acid occurred annually, except for 1999, between April and August, with smaller events occurring during late winter/early spring (April-May 2004, February 2006) and fall (October-November 2001, August-September 2004). The duration

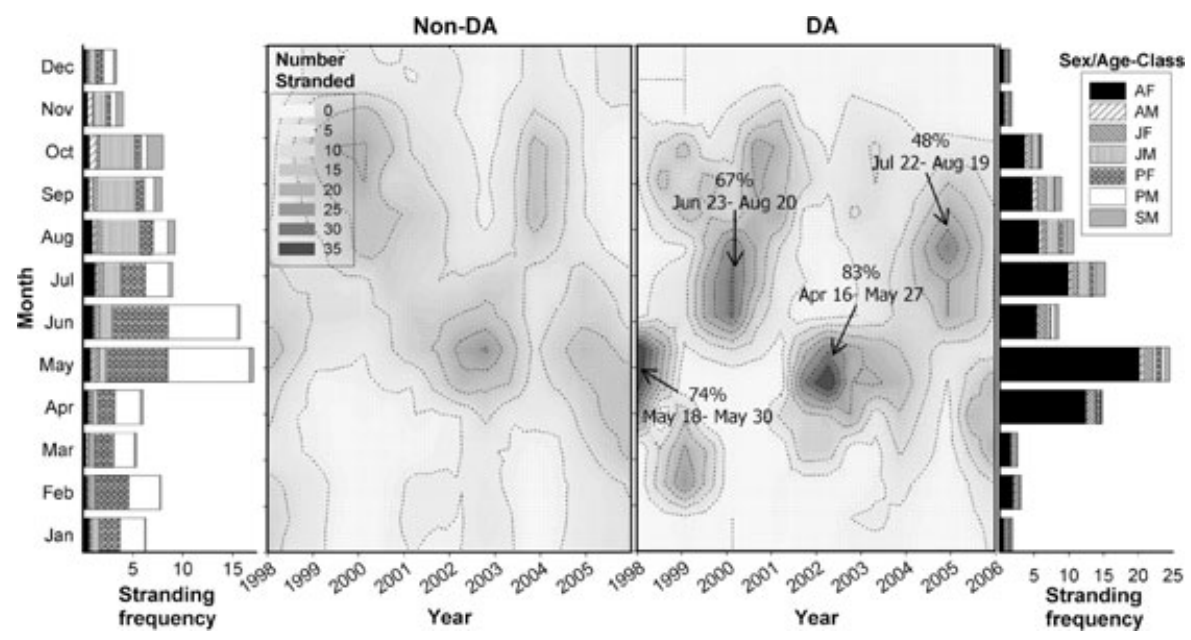

Figure 3. Temporal distribution of non-domoic acid and domoic acid sea lion strandings from 1998 to 2006. Side bar figure (left: non-domoic acid, right: domoic acid) represent the cumulative stranding frequency by month. In the domoic acid plot, the arrows highlight large domoic acid stranding events, which are presented as percent of total annual stranding during specific stranding peaks. $\mathrm{AF}=$ adult female, $\mathrm{AM}=$ adult male, $\mathrm{JF}=$ juvenile female, $\mathrm{JM}=$ juvenile male, $\mathrm{PF}=$ pup female, $\mathrm{PM}=$ pup male, and $\mathrm{SM}=$ subadult male. 


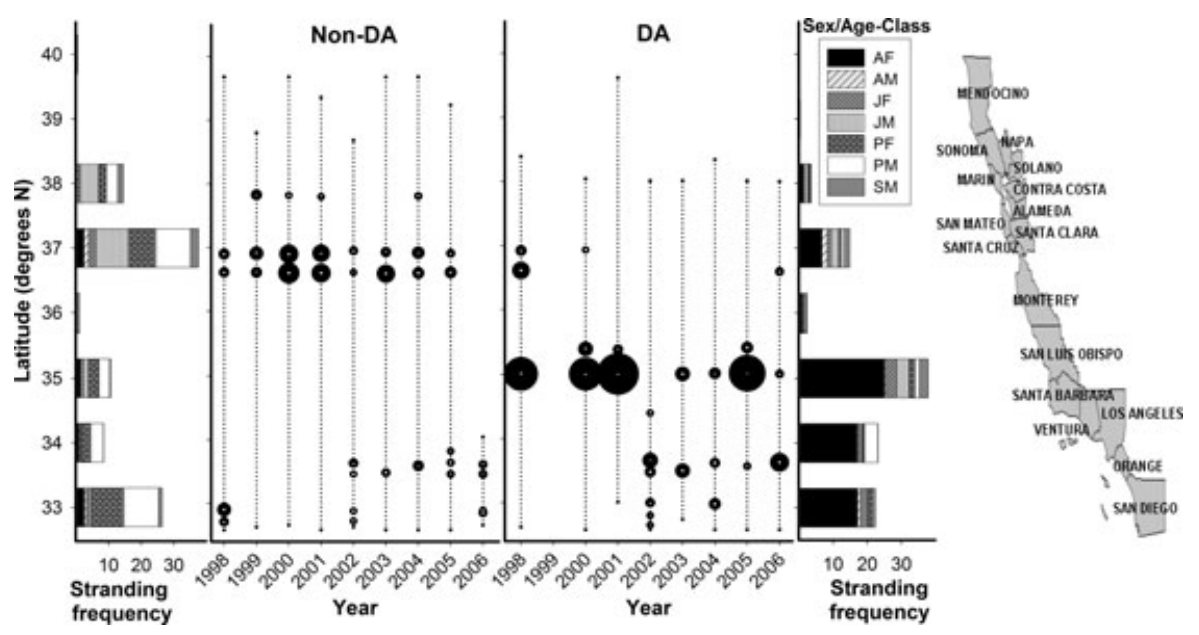

Figure 4. Latitudinal clusters of non-domoic acid and domoic acid cases from 1998 to 2006 (excluding 1999 domoic acid cases). The size of the circle represents the proportion of non-domoic acid or domoic acid annual stranded animals, while the center of the circle represents the geographical center of the cluster. The dotted lines show the latitudinal range along the California coastline where cases were reported. Only clusters containing $\geq 10 \%$ of the total annual strandings are shown. Side bar figures (left: non-domoic acid, right: domoic acid) represent the sex/age-class cumulative stranding frequency by latitudinal degree. The map on the right depicts the approximate cluster locations. $\mathrm{AF}=$ adult female, $\mathrm{AM}=$ adult male, $\mathrm{JF}=$ juvenile female, $\mathrm{JM}=$ juvenile male, $\mathrm{PF}=$ pup female, $\mathrm{PM}=$ pup male, and $\mathrm{SM}$ $=$ subadult male.

and severity of these annual domoic acid stranding events have varied over time. The most concentrated stranding peak occurred in 2002, where $83 \%$ of the total annual domoic acid cases stranded during a 42-d period. Other important peaks of stranding were identified in 1998,2000 , and 2005 , when $74 \%, 64 \%$, and $48 \%$ of the total domoic acid cases, respectively, occurred over a few weeks.

The spatial analysis (see Fig. 1 for reference) showed that strandings not related to domoic acid, with the exception of 2006, have covered most of the California coast encompassing 6.1-7.1 latitudinal degrees (ca. 672-788 km of coast line; Fig. 4). Relatively large clusters of cases not related to domoic acid containing 24\%-29\% of the total annual non-domoic acid strandings, centered at Monterey State Beach (Monterey County, MO) in 2000, 2001, and 2004 and at Seascape Beach (Santa Cruz County, SC) in 2000 and 2001. High latitudinal frequencies of these stranding cases centered around $37^{\circ} \mathrm{N}(37.6 \%)$ and $33^{\circ} \mathrm{N}(26 \%)$. While the strandings centered at $37^{\circ} \mathrm{N}$ comprised primarily of male pups and juvenile males $(11 \%$ and $10 \%$, respectively), the strandings centered at $33^{\circ} \mathrm{N}$ comprised mostly of female and male pups (11\% and $10 \%$, respectively).

By contrast, domoic acid strandings have generally occurred in large localized clusters. Within the time frame of this study, clusters of domoic acid cases have been unevenly spaced along the California coast, and strandings have covered 5.4-6.3 latitudinal degrees (ca. 586-700 km of coast line). Although domoic acid stranding clusters have varied in number and latitudinal location, large clusters have centered at Pismo Beach (San Luis Obispo County, SLO). In 1998, 2000, 2001, and 2005 
stranding clusters (covering an estimated $7-\mathrm{km}$ beach stretch) encompassing $47 \%$, $46 \%, 58 \%$, and $51 \%$, respectively, of the total annual domoic acid stranded animals, centered in this area. Adult females $(67 \% \pm 13 \%)$ and juveniles $(20 \% \pm 6 \%)$ were the predominant sex/age-classes present in these clusters. Other representative clusters (i.e., with $\geq 10 \%$ of the total annual domoic acid cases) centered at Monterey State Beach (MO, 24\%) and Seascape Beach (SC, 15\%) in 1998, Morro Bay (SLO, $20 \%$ ) and Davenport Beach (SC, 10\%) in 2000, Morro Strand State Beach (SLO, $14 \%$ ) in 2001, and Morro Strand State Beach (16\%) and Newport Beach (Orange County, OR, 11\%) in 2005. In 2002 there were six major clusters, all located in Southern California. These centered at San Onofre (OR, 21\%), Huntington Beach (OR, 15\%), Oceanside (San Diego County, SD, 13\%), Carpentaria State Beach (SB, $10 \%)$, Coronado (SD, 10\%), and Encinitas (SD, 10\%). Note that important domoic acid clusters in Orange and San Diego Counties (areas covered by PMMC) prior to 2002 may be missing because specific causes of death or stranding were not recorded prior to this year. While the two largest clusters in 2003 were also in OR and SLO counties (Newport Beach, 20\% and Pismo Beach, 20\%, respectively), the 2004 clusters centered at Pismo Beach (SLO, 16\%), Point Loma (SD, 16\%) and Laguna Beach (OR, 14\%). The main clusters in 2006 were centered at Pismo Beach, Laguna Beach and Monterey State Beach (12\%, 26\% and 12\%, respectively). High frequency of domoic acid cases centered at around $35^{\circ} \mathrm{N}(37.8 \%)$ and comprised $25 \%$ adult females.

\section{DISCUSSION}

Harmful algal blooms are a complex global phenomena affecting entire marine food webs and threatening both marine mammals and humans (Glibert et al. 2005). In the United States marine mammal mortality events associated with exposure to biotoxins, including domoic acid, appear to be increasing in frequency since the late 1990s, reflecting an increase in the occurrence of harmful algal blooms nationwide (Van Dolah 2005). This and previous studies (Gulland 2000, Scholin et al. 2000, Brodie et al. 2006) have unequivocally shown the toxic effects of Pseudo-nitzschia blooms on California sea lions. The records presented here included 1,335 confirmed or suspected domoic acid cases of which nearly half died directly from domoic acid toxicosis or indirectly from complications associated with intoxication. However, the total number of domoic acid casualties, including animals that stranded on inaccessible and infrequently visited beaches along the $\sim 1,000 \mathrm{~km}$ California coast and those that drowned at sea, is unknown, and likely much higher than the number presented here. A characteristic of the domoic acid stranding patterns shown here is that in five out of the nine years studied, the majority of strandings coincided with the sea lions' pupping and breeding seasons. This was the case in 2002, the year with the most domoic acid cases on record. Brodie et al. (2006) found reproductive failure in females exposed to domoic acid in 1998, which suggests that along with the direct and immediate increase in female mortality shown here, female exposure to this biotoxin prior to and during pupping may also increase the incidence of pup loss and/or related maternal complications.

Our analysis showed large demographic differences between animals that stranded from exposure to domoic acid and those that stranded from other causes. Although domoic acid impacts all age classes, the majority of cases have consistently been adult females (47\%-82\% of the total annual domoic acid cases). Greig et al. (2005) also 
reported that $54 \%$ ( 243 females) of the total live adult female strandings from 1991 to 2000 (449 females) resulted from domoic acid exposure. Adult females not only did strand in larger numbers across all seasons, but also stranded in larger proportions between Santa Barbara and San Mateo counties than adult females that stranded from other causes. Large numbers of female strandings may reflect differences in the structure of the population, as well as differences in aggregation patterns during bloom periods. Adult females on San Miguel Island and in the Gulf of California comprised at least 45\% of the annual resident population (Francis and Heath 1991, Maravilla-Chavez et al. 2006). During the breeding season females spend at least $50 \%$ of their time at sea traveling to and from feeding grounds, while adult males spend little or no time foraging at sea (Francis and Heath 1991). Thus, large female aggregations and increased time spent at sea (particularly diving for food) may increase their likelihood of exposure to domoic acid. Pseudo-nitzschia blooms have also occurred during the non-breeding season in the proximity of known foraging areas of females. Feeding grounds of lactating sea lions are located northwest of San Miguel Island along the central California coastline (Melin 2002), an area where high domoic acid concentration and density of Pseudo-nitzschia cells have been frequently quantified (CDHS 2000, 2002, 2005; Scholin et al. 2000). Males on the other hand, feed north of San Miguel Island up to Cape Mendocino $\left(39^{\circ} \mathrm{N}\right)$, and generally forage in different feeding grounds than females (Weise 2006). Furthermore, an important biotoxin vector, the northern anchovy Engraulis mordax, migrates in response to seawater temperature changes (Fleming 1999) and its high inshore abundance during late spring/summer and fall has coincided with the occurrence of Pseudo-nitzschia blooms. Thus, the geographic overlap of domoic acid producing phytoplankton, the biotoxin vector, and sea lion foraging locations may lead to increased incidence of intoxicated animals. To date, no evidence has been found to suggest increased female sea lion innate susceptibility to domoic acid toxicosis, substantiating ecological and behavioral differences as the best available explanation for their increased stranding frequency relative to other age classes.

Increased incidence of pup strandings not related to domoic acid during the summer coincides with the pupping and post-pupping season where pup mortality is normally high, particularly during the first months of life (Francis and Heath 1991, Spraker et al. 2007). The increased stranding frequency, primarily of pups, in May and June 2002 and 2003, was likely associated with El Niño (2003) and a decrease of resources for pregnant and/or lactating females and young pups. Although pups represent a small proportion of the total domoic acid cases (3.9\% this study; $1 \%$ Greig et al. 2005), it is possible that some of the pups that stranded for causes other than domoic acid may have been indirectly affected by this biotoxin. This may be the case for those pups whose mothers are exposed to domoic acid and are unable to return to the rookeries to continue nursing. Inadequate lactation prior to pup weaning may lead to emaciated pups without direct signs of exposure to domoic acid. However, the indirect effects of domoic acid on pup survival and overall health condition remain to be investigated.

Unfortunately, the lack of information on continuous Pseudo-nitzschia cell counts and/or measurements of domoic acid in the water column did not allow an evaluation of the co-occurrence of these blooms with the frequency, timing, and location of domoic acid strandings. However, the temporal analysis highlighted large domoic acid strandings (May 1998, June-July 2000, April-May 2002, and July-August 2005) consistent with the occurrence of generally well-described blooms along the California coast. Satellite imaging of chlorophyll- $a$ along central California showed 
high concentrations of plankton in a narrow band along the shore during the 1998 Pseudo-nitzschia bloom (Scholin et al. 2000). Water samples from this area collected between May and June contained up to $78 \mathrm{pg}$ domoic acid equivalents per $P$. australis cell and up to $71.3 \mu \mathrm{g}$ domoic acid equivalents/g gut tissue in domoic acid vectors (Scholin et al. 2000, Trainer et al. 2000). Lefebvre et al. (2002) also reported high concentration of Pseudo-nitzschia cells $\left(>10^{3}\right.$ cells/L) from July through October of 2000 in water samples from the Monterey Bay area, as well as elevated biotoxin concentration in two important prey species (anchovies and sardines; $>128$ $\mu \mathrm{g}$ domoic acid/g viscera), particularly during September (>558 $\mu \mathrm{g}$ domoic acid/g viscera). Similarly, in April 2002, the phytoplankton community near Point Conception was dominated by $P$. australis (Schwing et al. 2002), and from San Diego to San Luis Obispo Counties Pseudo-nitzschia cell abundance was relatively high ( $>10 \%$ of the total phytoplankton species) between April and May (CDHS 2002). In 2005, Pseudo-nitzschia abundance was also high during the first months of the year and highly abundant in August across several locations along the coast of San Luis Obispo.

The centers contributing records for our analyses did not provide coverage of the two most northerly counties, Humboldt and Del Norte; therefore, our spatial analyses did not extend north of $40^{\circ} \mathrm{N}$ latitude. However, sea lion strandings and specifically domoic acid cases were relatively rare in the county immediately south (Mendocino), which is covered by TMMC. Conditions that favor the development of $P$. australis blooms (cyclonic eddies) and consequently the production of domoic acid have been noted to be favorable along the central and southern California coast (Anderson $e t$ al. 2006), in close proximity to sea lion breeding and feeding grounds (Melin 2002). Therefore, targeting stranding records from the southern and central areas of the California coast to examine domoic acid cases was determined to be most efficient. The two counties from which data were not available annually contribute less than $1 \%$ of the total sea lion stranding records to the national database (NOAA Fisheries Marine Mammal Health and Stranding Response database); therefore, acquiring additional records from these counties would be unlikely to significantly alter our results. Variability in recovery efforts and accessibility to beaches could have factored into the spatial clustering of strandings. However, recovery efforts were consistent for domoic acid and other cause cases; therefore, the differences in spatial clustering of domoic acid cases cannot be attributed to variability in recovery efforts. Greig et al. (2005) reported that the majority of live sea lions (74\%) admitted to TMMC between 1991 and 2000 stranded in Santa Cruz, Monterey and San Luis Obispo Counties, with most admissions (83\%) occurring between May and October. That study identified geographic clusters of domoic acid cases in San Luis Obispo (Nipomo/Guadalupe Dunes) and Monterey (Pfeiffer State Beach) counties. In the current study, domoic acid clusters centered at Pismo Beach (San Luis Obispo County), an area that contained nearly half of the total annual domoic acid cases from 1998, 2000, 2001, and 2005. The shoreline of San Luis Obispo, has frequently exhibited high Pseudo-nitzschia densities and high domoic acid concentrations (CDHS 2000, 2002, 2005; Anderson et al. 2006). The localized toxic blooms mentioned herein may also explain the relatively small proportion of domoic acid strandings $(<3 \%)$ north of San Mateo County.

This and other studies (Gulland 2000, Scholin et al. 2000, Gulland et al. 2002, Greig et al. 2005, Brodie et al. 2006, Goldstein et al. 2008) have documented strandings and mortalities from exposure to domoic acid, yet little is known regarding implications on the overall population. Additional studies are needed to assess the 
likelihood that domoic acid poses a long-term threat to California sea lions and other marine mammal populations. Such studies will rely heavily on continued efforts and data collection by stranding networks.

\section{ACKNOWLEDGMENTS}

We thank NOAA Fisheries Marine Mammal Health and Stranding Response Program and NOAA's Ocean Service/Hollings Marine Lab for funding support. We also extend our thanks to those dedicated to the care of stranded animals and to those involved with the efforts of the California Marine Mammal Stranding Network. This publication does not constitute an endorsement of any commercial product or intend to be an opinion beyond scientific or other results obtained by the National Oceanic and Atmospheric Administration (NOAA). No reference shall be made to NOAA, or this publication furnished by NOAA, to any advertising or sales promotion, which would indicate or imply that NOAA recommends or endorses any proprietary product mentioned herein, or which has as its purpose an interest to cause the advertised product to be used or purchased because of this publication.

\section{Literature Cited}

Anderson, C. R., M. A. Brzezinski, L. Washburn and R. Kudela. 2006. Circulation and environmental conditions during a toxigenic Pseudo-nitzschia bloom in the Santa Barbara Channel, California. Marine Ecology Progress Series 327:119-133.

Bartholomew, G. A. 1967. Seal and sea lion populations of the California Islands. Proceedings of the symposium on the biology of the California Islands, Santa Barbara Botanic Gardens, Santa Barbara, CA. Pp. 229-244.

Brodie, E. C., F. M. D. Gulland, D. J. Greig, M. Hunter, J. Jahkola, J. St. Leger, T. A. Leighrield and F. M. Van Dolah. 2006. Domoic acid causes reproductive failure in California sea lions (Zalophus californianus). Marine Mammal Science 22:700707.

CDHS (California Department of Health Services). 2000. Monthly Marine Biotoxin Report: April-June 2000. Berkeley, CA. 20 pp.

CDHS (California Department of Health Services). 2002. Marine Biotoxin Monitoring Program: Annual report 2002. Berkeley, CA. 115 pp.

CDHS (California Department of Health Services). 2005. Marine Biotoxin Monitoring Program: Annual report 2005. Berkeley, CA. 44 pp.

Chavez, F. P., J. Ryan, S. E. Lluch-CotA AND M. Ñiquen. 2003. From anchovies to sardines and back: Multidecadal change in the Pacific Ocean. Science 299:217-221.

Cleveland, W. S. 1993. Visualizing data. Hobart Press, Summit, NJ.

DeLong, R. L., W. G. Gilmartin AND J. G. Simpson. 1973. Premature births in California sea lions: Association with high organochlorine pollutant residue levels. Science 181:11681170 .

Delong, R. L., G. A. Antonelis, C. W. Oliver, B. S. Stewart, M. S. Lowry and P. K. YoCHEM. 1991. Effects of the 1982-1983 El Niño on several population parameters and diet of california sea lions on the California Channel Islands. Pages 166-172 in F. Trillmich and K. A., Ono, eds. Pinnipeds and El Niño: Responses to environmental stress. Springer-Verlag, Berlin, Germany.

Dierauf, L., D. J. Vandenbroek, J. Roletto, M. Koski, L. Amaya and L. J. Gage. 1985. An epizootic of leptospirosis in California sea lions. Journal of the American Veterinary Medical Association 187:1145-1148.

Fleming, K. 1999. Northern anchovy. Pages 167-178 in J. J. Orsi, ed. Report on the 19801995 Fish, shrimp, and crab sampling in the San Francisco Estuary, California. Technical Report 63. California Department of Fish and Game, Stockton, CA. 
FranCis, J. M., AND C. B. Heath. 1991. Population abundance, pup mortality, and copulation frequency in the California sea lion in relation to the 1983 El Niño on San Nicolas Island. Pages 271-288 in F. Trillmich and K. A., Ono, eds. Pinnipeds and El Niño: Responses to environmental stress. Springer-Verlag, Berlin, Germany.

Glibert, P. M., D. M. Anderson, P. Gentien, E. Granéli and K. G. Sellner. 2005. The global, complex phenomena of harmful algal blooms. Oceanography 18(2):136-147.

Goldstein, T., J. A. K. Mazet, T. S. Zabra, G. Langlois, K. M. Colegrove, M. Silver, S. Bargu, F. Van Dolah, T. Leighfield, P. A. Conrad, J. Barakos, D. C. Williams, S. Dennison, M. Haulena and F. M. D. Gulland. 2008. Novel symptomatology and changing epidemiology of domoic acid toxicosis in California sea lions (Zalophus californianus): An increasing risk to marine mammal health. Proceedings of the Royal Society of London B 275:267-276.

Greig, D. J., F. M. D. Gulland And C. Kreuder. 2005. A decade of live California sea lion (Zalophus californianus) strandings along the central California coast: Causes and trends, 1991-2000. Aquatic Mammals 31:40-51.

Gulland, F. 2000. Domoic acid toxicity in California sea lions (Zalophus californianus) stranded along the central California coast, May-October 1998 NOAA Technical Memorandum, NMFS-OPR, 17. 45 pp.

Gulland, F. M. D., AND A. J. Hall. 2007. Is marine mammal health deteriorating? Trends in the global reporting of marine mammal disease. EcoHealth 4:135-150.

Gulland. F. M. D., M. Koski, L. J. Lowenstine, A. Colagross, L. Morgan and T. Spraker. 1996. Leptospirosis in California sea lions (Zalophus californianus) stranded along the central California coast, 1981-1994. Journal of Wildlife Diseases 32:572-580.

Gulland, F. M. D., M. Haulena, D. Fauquier, G. Langlois, M. E. Lander, T. Zabka And R. Duerr. 2002. Domoic acid toxicity in Californian sea lions (Zalophus californianus): Clinical signs, treatment and survival. Veterinary Record 150:475-480.

Hampson, D. R., AND J. L. Manalo. 1998. The activation of glutamate receptors by kainic acid and domoic acid. Natural Toxins 6:153-158.

Horner, R. A., D. L. Garrison And F. G. Plumley FG. 1997. Harmful algal blooms and red tide problems on the U.S. west coast. Limnology and Oceanography 42:1076-1088.

Kaufman, L., AND P. J. Rousseeuw. 1990. Finding groups in data: An introduction to cluster analysis. John Wiley and Sons, Inc., New York, NY.

Le Bouef, B. J., M. L. Bonnell, M. O. Pierson, D. H. Dettman and B. D. Farrens. 1976. Pinnipedia: Numbers, distribution and movements in the Southern California Bight. Page HI-1-269 in Regents of the University of California, eds. Section I, Marine mammal and seabird survey of the Southern California Bight area, Draft Final Report 1975-1976, BLM contract 08550-CTS-28.

Lefebvre, K. A., M. Silver, S. Coale And R. TJeerdema. 2002. Domoic acid in planktivorous fish in relation to toxic Pseudo-nitzschia cell densities. Marine Biology 140:625-631.

LOWRy, M. S., AND K. A. Forney. 2005. Abundance and distribution of California sea lions (Zalophus californianus) in central and northern California during 1998 and summer 1999. Fisheries Bulletin 103:331-343.

Lowry, M. S., AND O. Maravilla-Chavez. 2005. Recent Abundance of California Sea Lions in Western Baja California, Mexico and the United States. Pages 485-498 in D. K. Garcelon and C. A. Schwemm, eds. Proceedings of the Sixth California Islands Symposium. National Park Service Technical Publication CHIS-05-01, Institute for Wildlife Studies, Arcata, CA.

MAte, B. R. 1975. Annual migrations of the sea lions Eumetopias jubatus and Zalophus californianus along the Oregon coast. Rapports et Procès-verbaux des réunions, Conseil Permanent International pour l'Exploration de la Mer 169:455-461.

Mazet, J., G. Torres dela Riva, F. Gulland, G. Langlois and C. Kreuder. 2005. Marine mammal strandings associated with toxic algal blooms along the California coastline in 2002. Research Agreement Number DG133F-02-SE-0869. Wildlife Health Center, School of Veterinary Medicine, University of California, Davis, CA. 
Maravilla-Chavez, M. O., A. Zavala-GonZalez and A. Ortega-Rubio. 2006. Four seasons abundance changes of Zalophus californianus californianus (Lesson 1828), Allen, 1880, in the Gulf of California, Mexico. Brazilian Archives of Biology and Technology 49:111116.

Melin, S. R. 2002. The foraging ecology and reproduction of the California sea lion (Zalophus californianus californianus). Ph.D. dissertation, University of Minnesota, Minneapolis, MN. 169 pp.

NMFS (NATIONAl MARINE FiShERIES SERVICE). 2003. California sea lion (Zalophus californianus californianus): U.S. Stock. Marine Mammal Stock Assessment Report. Office of Protected Resources, NOAA Fisheries, Silver Spring, MD. 7 pp.

Odell, D. K. 1981. California sea lion-Zalophus californianus. Pages 67-98 in S. H. Ridgway and R. J. Harrison, eds. Handbook of marine mammals. Volume 1. The walrus, sea lions, fur seals and sea otter. Academic Press, London, U.K.

Peterson, R. S., And G. A. BARTholomew. 1967. The natural history and behavior of the California sea lion. The American Society of Mammalogists, Stillwater, OK. 79 pp.

Raverty, S. A., D. M. Lambourn, S. J. Jeffries, C. E. Cameron, S. A. Norman, R. Zuerner, W. SZANiszlo, P. Olesiuk AND F. Gulland. 2005. Incursion of Leptospira interrogans, serovar pomona into the Pacific north west by migratory subadult and adult California sea lions (Zalophus californianus). Proceedings of the 36th Annual Conference of the International Association for Aquatic Animal Medicine, Seward, AK. Pp. 245-247.

Scholin, C. A., F. M. Gulland, G. J. Doucette, S. Benson, M. Busman, F. P. Chavez, J. Cordaro, R. Delong, A. De Vogelaere, J. Harvey, M. Haulena, K. Lefebvre, T. Lipscomb, S. Loscutoff, L. J. Lowenstine, R. III. Marin, P. E. Miller, W. A. Mclellan, P. D. R. Moeller, C. L. Powell, T. Rowles, P. Silvagni, M. Silver, T. Spraker, V. Trainer and F. M. VAN DOlah. 2000. Mortality of sea lions along the central California coast linked to a toxic diatom bloom. Nature 403:80-84.

Schwing, F. B., S. J. Bograd, C. A. Collins, G. Gaxiola-Castro, J. Garcia, R. Goericke, J. Gomez-Valdez, A. Huyer, K. D. Hyrenbach, P. M. Kosro, B. E. Lavaniegos, R. J. Lynn, A. W. Mantyla, M. D. Ohman, W. T. Peterson, R. L. Smith, W. J. Sydeman, E. Venrick AND P. A. WheEler. 2002. The state of the California Current, 2001-2002: Will the CCS keep its cool, or is El Niño looming? CalCOFI Reports 43:29-62.

Smith, A. W., R. J. Brown, D. E. Skilling And R. L. DeLong. 1974. Leptospira pomona and reproductive failure in California sea lions. Journal of the American Veterinary Medical Association 165:996-998.

SOKAL, R. R., AND F. J. ROHLF. 1995. Biometry: The principles and practice of statistics in biological research. 3rd edition. W.H. Freeman and Co., New York, NY.

Spraker, T. R., R. L. DeLong, E. T. LyOns and S. R. Melin. 2007. Hookworm enteritis with bacteremia in California sea lion pups on San Miguel Island. Journal of Wildlife Diseases 43:179-188.

Trainer, V. L., N. G. Adams, B. D. Bill, C. M. Stehr, J. T. Wekell, P. Moeller, M. Busman AND D. WoOdRufF. 2000. Domoic acid production near California upwelling zones, June 1998. Limnology and Oceanography 45:401-440.

Trillmich, F., AND K. A. ONO. 1991. Pinnipeds and El Niño: Responses to environmental stress. Springer-Verlag, Berlin, Germany.

VAN Dolah, F. M. 2005. Effects of harmful algal blooms on marine mammals: information needs and prospects for management. Pages 85-99 in J. Reynolds, W. F. Perrin, R. R. Reeves, S. Montgomery and T. J. Ragen, eds. Marine mammal conservation: Beyond crisis management. Johns Hopkins University Press, Baltimore, MD.

Weise, M. J. 2006. Foraging ecology of male California sea lion (Zalophus californianus): Movement, diving and foraging behavior, and diving capacity. Ph.D. dissertation, University of California, Santa Cruz, CA. 137 pp. 